\title{
Antisense CCAAT/enhancer-binding protein RNA suppresses coordinate gene expression and triglyceride accumulation during differentiation of 3T3-L1 preadipocytes
}

\author{
Fang-Tsyr Lin and $M$. Daniel Lane ${ }^{1}$ \\ Department of Biological Chemistry, The Johns Hopkins University School of Medicine, Baltimore, Maryland 21205 USA
}

\begin{abstract}
Previous studies suggest that the CCAAT/enhancer-binding protein (C/EBP) functions in the coordinate expression of adipocyte genes during differentiation of 3T3-L1 preadipocytes. We sought to block expression of C/EBP selectively using a bovine papilloma virus (BPV) vector to direct transcription of a $\sim 0.4-\mathrm{kb}$ segment of C/EBP cDNA (in antisense orientation) containing translated sequence 5 ' to that encoding the basic and leucine zipper regions of the protein. Vector-directed expression of antisense C/EBP RNA in 3T3-L1 preadipocytes inhibited expression of C/EBP mRNA and protein, as well as several adipose-specific mRNAs, and also prevented cytoplasmic triglyceride accumulation. Rescue of the "adipocyte phenotype" was accomplished by transfection of cells expressing antisense RNA with a modified BPV vector that directs transcription of the complementary sense C/EBP RNA.
\end{abstract}

[Key Words: C/EBP; adipocyte genes; 3T3-L1 preadipocytes]

Received November 26, 1991; revised version accepted February 10, 1992.

With appropriate hormonal stimulation, confluent 3T3$\mathrm{L} 1$ preadipocytes in cell culture differentiate into cells possessing the biochemical and morphological characteristics of adipocytes (Green and Kehinde 1974, 1975, 1976; Mackall et al. 1976; Coleman et al. 1978; Rosen et al. 1979; Reed and Lane 1980; Student et al. 1980). Acquisition of the adipocyte phenotype is preceded by a dramatic and coordinate rise in the transcription of a group of adipose-specific genes including the 422(aP2), SCD1, and GLUT4 genes (Bernlohr et al. 1985; Cook et al. 1985; Kaestner et al. 1990). In several laboratories considerable effort has been directed at defining the basis of the coordinate differentiation-linked transcriptional activation of such adipocyte-specific genes. The promoters of several of these genes have been analyzed (Phillips et al. 1986; Cook et al. 1988; Ntambi et al. 1988; Kaestner et al. 1990) and shown to drive the expression of reporter genes when subjected to agents that act as inducers of preadipocyte differentiation (Cook et al. 1988; Ntambi et al. 1988).

Recent evidence has implicated the CCAAT/enhancer-binding protein $(\mathrm{C} / \mathrm{EBP})$ in the transcriptional activation of adipocyte-specific genes during the differentiation of 3T3-L1 preadipocytes. C/EBP was identified as

${ }^{1}$ Corresponding author. a differentiation-induced nuclear factor that binds specifically to the promoters of three genes [the 422(aP2), SCD1, and GLUT4 genes] that are coordinately expressed when 3T3-Ll preadipocytes differentiate into adipocytes (Christy et al. 1989; Kaestner et al. 1990). Consistent with a role for C/EBP in coordinating adipocyte gene expression, the C/EBP gene is activated transcriptionally just before expression of $422(\mathrm{aP} 2), \mathrm{SCD} 1$, and GLUT4 mRNAs (Birkenmeier et al. 1989; Christy et al. 1989). Both in intact 3T3-L1 cells (Christy et al. 1989; Kaestner et al. 1990) and with a cell-free transcription system, it was demonstrated further (Cheneval et al. 1991) that C/EBP can function as a trans-activator of the promoters of these genes. Mutation of the C/EBP-binding site within these gene promoters obliterates transactivation (Christy et al. 1989; Herrera et al. 1989; Cheneval et al. 1991). Moreover, the premature activation (by estrogen) of a constitutively expressed, but inactive, $\mathrm{C} / \mathrm{EBP}-$ estrogen receptor fusion protein caused premature expression of $422(\mathrm{aP} 2) \mathrm{mRNA}$ relative to the normal differentiation program (Umek et al. 1991). These findings provide compelling, although circumstantial, evidence for the involvement of C/EBP in differentiation-induced gene expression in 3T3-L1 preadipocytes.

The aim of the present investigation was to block expression of C/EBP selectively during preadipocyte differ- 
entiation with an antisense C/EBP RNA expression vector and to assess the effects of this blockade on the transcription of adipocyte genes. To obtain a high level of expression of the antisense or sense C/EBP RNA, we used a bovine papilloma virus (BPV) expression vector that is carried at a high copy number in animal cells. This vector, pBCMGNeo (Karasuyama et al. 1989), contains a $69 \%$ BPV subgenomic fragment (Lowy et al. 1980) that is maintained as a multicopy episome (Law et al. 1981; Sarver et al. 1981; DiMaio et al. 1982). The vector also contains a strong human cytomegalovirus (CMV) promoter with which to drive expression of inserted cDNAs (Boshart et al. 1985). In this paper we demonstrate that expression of antisense C/EBP RNA in 3T3L1 preadipocytes blocks the expression of several adipocyte genes and prevents cytoplasmic triglyceride accumulation. Rescue of the "adipocyte phenotype" was accomplished by transfection with another vector that directs the transcription of sense C/EBP RNA in cells expressing the antisense RNA.

\section{Results}

Transfection of 3T3-L1 cells with expression vectors encoding partial antisense and sense C/EBP RNAs

Previous investigations have provided indirect evidence for the involvement of C/EBP in the transcriptional activation of the promoters of several adipocyte genes in 3T3-L1 preadipocytes (Christy et al. 1989; Kaestner et al. 1990). To test directly the hypothesis that C/EBP is necessary for coordinate expression of these genes during preadipocyte differentiation, we sought to block expression of C/EBP specifically with an antisense C/EBP RNA expression vector. Thereforc, a $\mathrm{BPV}$ vector containing a segment of the C/EBP cDNA in the antisense orientation was constructed.

To construct the antisense C/EBP expression vector, pBCMGAS, the $\sim 0.4-\mathrm{kb}$ HincII-Smal segment of the C/EBP gene containing translated sequence $5^{\prime}$ to that encoding the basic and leucine zipper regions of the protein was inserted into the XhoI site of the pBCMGNeo expression vector (Karasuyama et al. 1989) in the antisense (or sense; see below) orientation placing it under the control of the human cytomegalovirus (CMV) gene promoter (Fig. 1). Because the nucleotide sequence of the $\sim 0.4$-kb segment of the C/EBP gene is not homologous to other members of the $\mathrm{C} / \mathrm{EBP}$ gene family or to other proteins in the GenBank rodent data base, expression of the antisense RNA would be expected to interfere selectively with transcription of the C/EBP gene and the translation or stability of its mRNA. Importantly, the parental pBCMGNeo vector contains the necessary BPV sequences for extrachromosomal (nuclear episomal) replication of multiple copies of the vector in mammalian cells. The vector also contains a gene for selection of resistance to neomycin.

The antisense C/EBP expression vector, pBCMGAS, or the pBCMGNeo vector that lacks the insert, was transfected into 3T3-Ll preadipocytes by electroporation after which selection with G418 was performed. Three neomycin-resistant clonal cell lines (AS1, AS2, and AS3 cells) that harbored the pBCMGAS vector were selected for further analysis. Southern blots of XhoI digests of low-molecular-weight DNA isolated from AS1, AS2, and AS3 cells (Fig. 2A) indicated the presence of the extrachromosomal vector containing the $\sim 0.4$-kb insert of the C/EBP gene, with AS3 cells exhibiting the highest content of the antisense construct. The relative intensities on Southern blots (quantitated by laser densitometric scanning) of the $0.4 \mathrm{~kb}$-band derived from low-molecular-weight cellular DNA were compared with that derived from a known quantity of pBCMGAS DNA. We estimate that AS1, AS2, and AS3 cells contain at least five, four, and eight copies, respectively, of extrachromosomal pBCMGAS per cell (Table 1). This is likely to be an underestimate in view of the typically low recovery $(<50 \%)$ of extrachromosomal DNA.

In addition to being replicated extrachromosomally, after multiple passages of AS1, AS2, and AS3 cells, the antisense C/EBP expression vector also became integrated into chromosomal DNA (Table 1). Thus, digestion of high-molecular-weight chromosomal DNA with $X$ hoI, which removes the $\sim 0.4-\mathrm{kb}$ antisense C/EBP insert from the vector, gave rise to the $\sim 0.4-\mathrm{kb}$ fragment, as well as an $\sim 11-\mathrm{kb}$ fragment derived from the endogenous C/EBP gene (Fig. 2B). Quantitation of the relative intensities of the two bands indicates that AS1, AS2, and AS3 cells contain $\sim 4,10$, and 9 copies per cell, respectively, of an integrated form of the antisense C/EBP expression vector. In all experiments described below, cells that had been passaged 15-20 times were used.

Expression of antisense C/EBP RNA and its effect on the expression of C/EBP, 422(aP2), SCD1, and GLUT4

To ascertain whether 3T3-L1 cells harboring the pBCMGAS vector express antisense C/EBP RNA, RNA was isolated from both transfected and untransfected cells at various times (on days 0, 2, and 4) after the induction of differentiation. As indicated by RNase protection analysis (Fig. 3A), antisense C/EBP RNA was expressed in all three cell lines (i.e., AS1, AS2, and AS3 cells), the highest level of antisense C/EBP RNA occurring in AS3 cells followed by AS2 and AS1 cells. Northern blots confirmed that the antisense RNA expressed in AS3 was of the predicted size (results not shown).

Control cell lines transfected with the pBCMGNeo vector lacking an antisense or sense $\mathrm{C} / \mathrm{EBP}$ insert expressed normal levels of C/EBP and 422(aP2) mRNA (Fig. 3B) and, as discussed below, differentiated into adipocytes. In contrast, cell lines harboring the pBCMGAS vector exhibited a reduced level of C/EBP mRNA that correlated closely with the level of expression of antisense C/EBP RNA (Fig. 3A). Thus, AS3 and AS2 cells that express the highest levels of antisense C/EBP RNA (as compared with ASl cells) exhibited virtually complete suppression of endogenous C/EBP mRNA when compared with untransfected 3T3-L1 cells or cells transfected with the pBCMGNeo vector lacking an insert (Fig. 
A

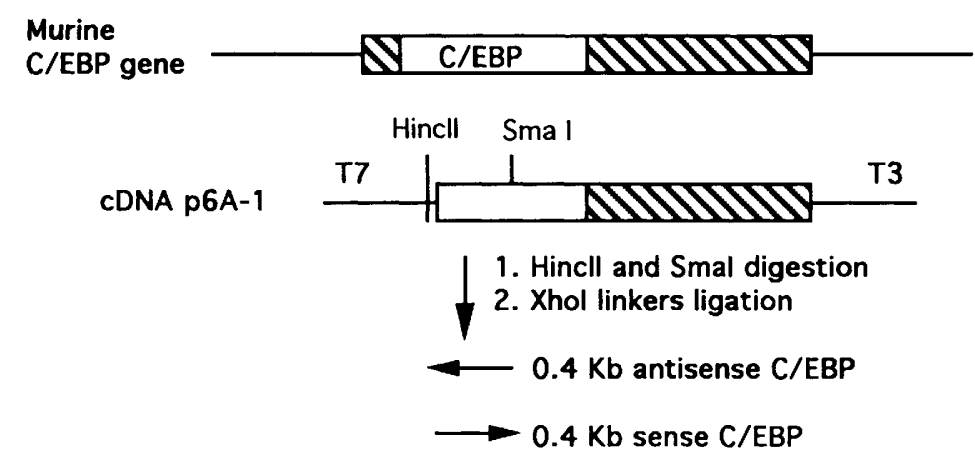

B
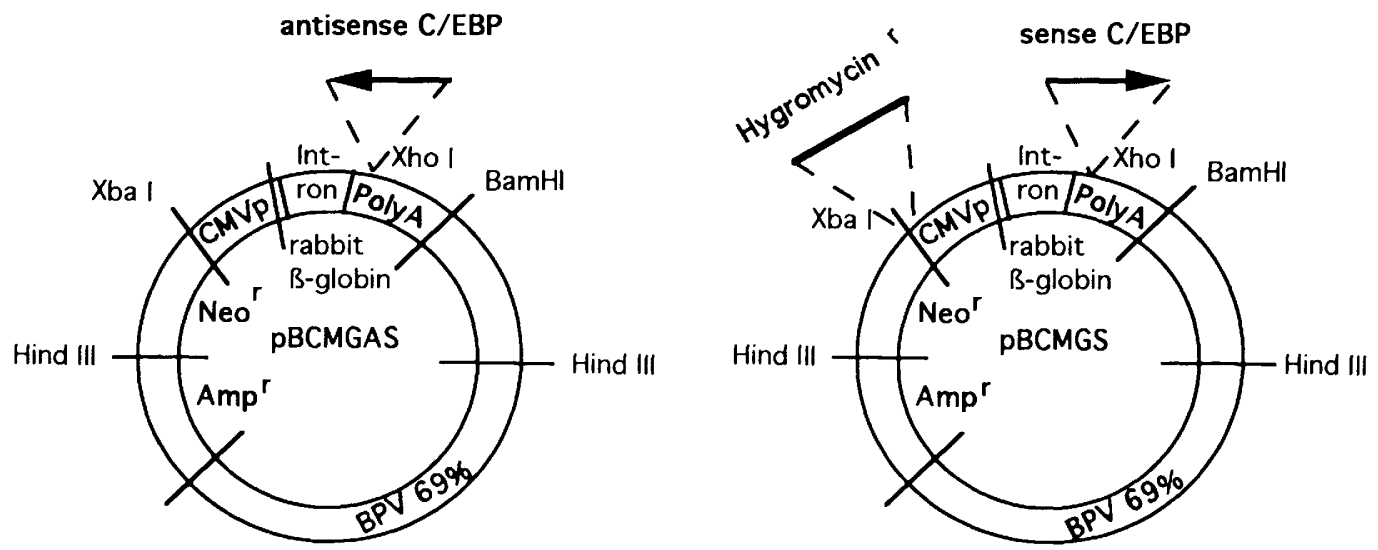

Figure 1. Construction of partial antisense and sense C/EBP RNA expression vectors. $(A)$ Map of the murine C/EBP gene (from Christy et al. 1991). The open box corresponds to coding sequences; the hatched boxes correspond to the $5^{\prime}$ or $3^{\prime}$-untranslated sequences. p6A-1 is a cDNA containing nucleotides +490 to the poly $(\mathrm{A})^{+}$tail of C/EBP cDNA (Christy et al. 1991), which was inserted into the EcoRI site of pBluescript. A $\sim 0.4-\mathrm{kb}$ C/EBP fragment corresponding to nucleotides +490 to +870 of $\mathrm{C} / \mathrm{EBP} \mathrm{cDNA}$ was isolated by digestion of p6A-1 at the HinclI site in pBluescript and the SmaI site of the translated sequences $5^{\prime}$ to that encoding basic and leucine zipper regions of C/EBP. $(B)$ The parental 14.8-kb pBCMGNeo expression vector contains a $69 \%$ BPV subgenomic fragment permitting extrachromosomal replication and contains a neomycin-resistance gene for selection. The $\sim 0.4-\mathrm{kb} C / \mathrm{EBP}$ fragment was inserted into the $\mathrm{Xhol}$ site of $\mathrm{pBCMGNeo}$ in the sense or antisense orientation, placing these sequences under the control of human CMV gene promoter. The antisense plasmid, pBCMGAS, and the control plasmid, pBCMGNeo, were transfected into 3T3-L1 preadipocytes. A hygromycin-resistance gene was inserted into the sense plasmid, which is designated pBCMGS. The control vector, $\mathrm{pBCMGHyg}$, was obtained by removing the $\sim 0.4-\mathrm{kb}$ C/EBP insert from pBCMGS.

3B|. AS1 cells that expressed the lowest level of antisense C/EBP RNA expressed a reduced, but significant, level of C/EBP mRNA (Fig. 3A). It should be noted that although antisense RNA can lead to a reduced cellular level of its corresponding mRNA (Knecht and Loomis 1987; Yokoyama and Imamoto 1987), it need not, as formation of RNA-RNA hybrids does not guarantee decreased message stability. Nevertheless, hybridization of antisense RNA to pre-mRNA or to fully spliced mRNA would be expected to interfere with translation (Izant and Weintraub 1984; Kim and Wold 1985; Melton 1985).

Consistent with trans-activation by C/EBP of the promoters of the $422(\mathrm{aP} 2), \mathrm{SCD} 1$, and GLUT4 genes (Christy et al. 1989; Kaestner et al. 1990), blocking expression of the C/EBP gene appears to repress the differentiation-induced increases in the levels of 422(aP2), SCD1, and GLUT4 mRNAs. Cells harboring the an- tisense C/EBP RNA expression vector exhibited markedly decreased levels of 422(aP2) mRNA, the level being lowest in cells expressing the highest level of antisense C/EBP RNA (Fig. 3A). Thus in the AS3 cell line in which antisense C/EBP RNA virtually eliminated expression of C/EBP mRNA, expression of $422(\mathrm{aP} 2)$ mRNA was almost completely suppressed (Fig. 3A).

Suppression of C/EBP and 422(aP2) mRNA levels caused by expression of C/EBP antisense RNA leads to a reduction of the cellular levels of the proteins that they encode. Thus, Western blot analysis of cell extracts revealed that cells harboring the antisense C/EBP RNA expression vector contained greatly reduced levels of $\mathrm{C} / \mathrm{EBP}$ protein (Fig. $4 \mathrm{~A})$ and $422(\mathrm{aP2})$ protein (Fig. $4 \mathrm{~B}$ ) compared with wild-type 3T3-Ll adipocytes or 3T3-L1 adipocytes harboring the control BCMGNeo vector. Of interest is the fact that expression of an apparent trun- 

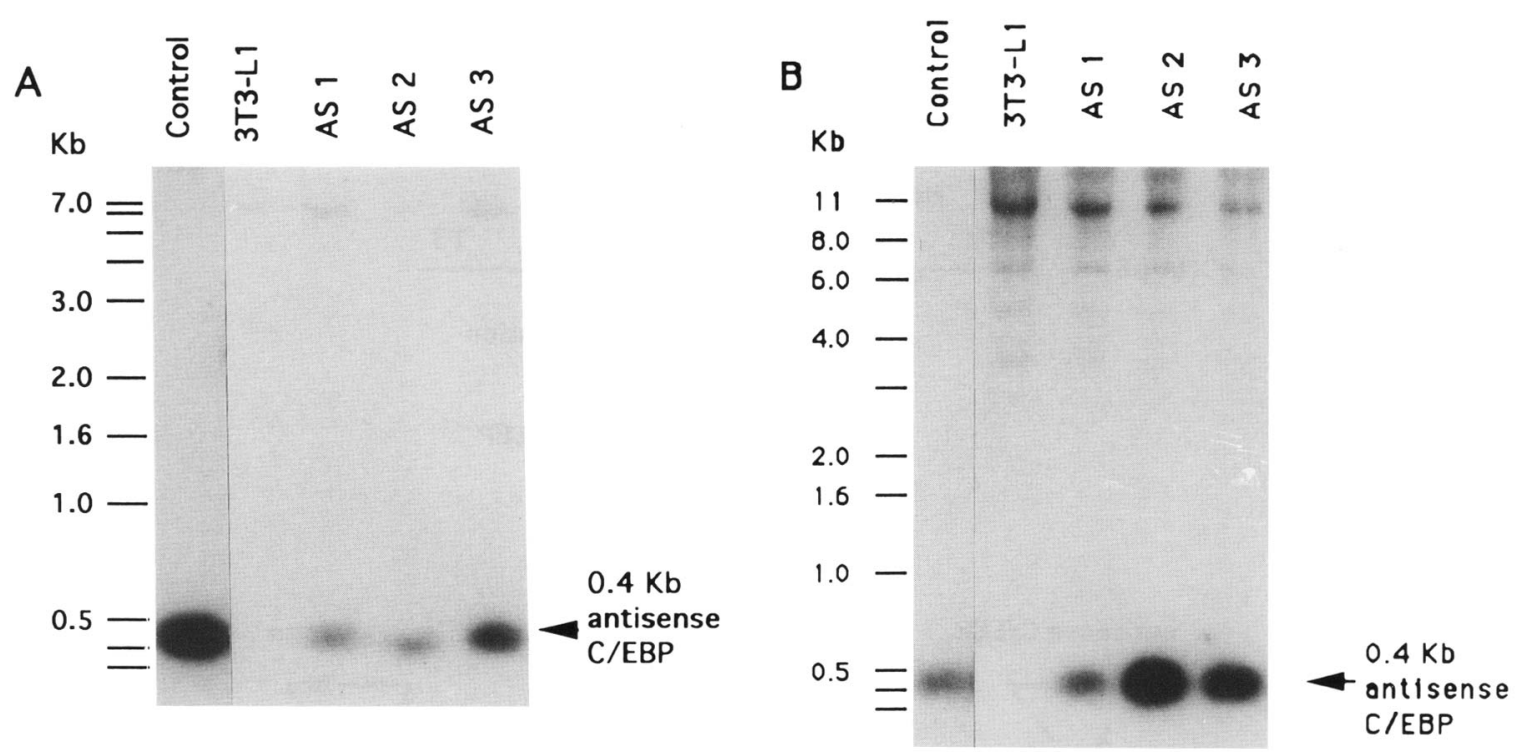

Figure 2. Southern blot analysis on DNA from the antisense (AS) cell lines. (A) Low-molecular-weight (extrachromosomal) DNA from two $100-\mathrm{mm}$ dishes of confluent $3 \mathrm{~T} 3-\mathrm{Ll}$ and AS cells and $1 \mathrm{ng}$ of pBCMGAS were digested with XhoI and subjected to electrophoresis on $0.7 \%$ agarose gel. Southern blots were prepared and hybridized with the ${ }^{32} \mathrm{P}$-labeled $\sim 0.4-\mathrm{kb} \mathrm{C} / \mathrm{EBP}$ fragment obtained by digestion of pBCMGAS with XhoI. $\{B)$ High-molecular-weight (chromosomal) DNA $(20 \mu \mathrm{g})$ prepared from 3T3-Ll and AS cells and $0.1 \mathrm{ng}$ of pBCMGAS were digested with $\mathrm{XhOl}$ followed by Southern blot analysis using the same probe as in $A$.

cated $\sim 30-\mathrm{kD}$ form of $\mathrm{C} / \mathrm{EBP}$ is also markedly reduced in cells harboring the antisense RNA expression vector (Fig. 4A). We suggest that the $30-\mathrm{kD}$ protein, which is recognized by antibodies against $\mathrm{C} / \mathrm{EBP}$, represents the product of translation initiated at a methionine that lies downstream from the methionine at which translation of "full-length" C/EBP is initiated. A similar situation in which more than a single translational initiation site is used has been demonstrated for the related liverenriched transcriptional activator protein (LAP) (Descombes and Schibler 1991).

In addition to causing a decrease in the level of 422(aP2) mRNA, antisense C/EBP RNA - apparently by suppressing expression of $\mathrm{C} / \mathrm{EBP}$-also caused a decrease in the levels of SCD1 and GLUT4 mRNAs. As illustrated in Figure 5, AS1 and AS3 cells harboring the antisense C/EBP vector exhibited drastically reduced levels of SCD1 and GLUT4 mRNAs compared with control 3T3Ll cells. Taken together, these results implicate C/EBP in the coordinate expression of a group of adipocyte genes during the differentiation of 3T3-L1 preadipocytes.

\section{Effect of expression of antisense C/EBP RNA on the rates of nuclear run-on transcription of the C/EBP and 422( $(\mathrm{P} 2)$ genes}

To determine whether the decrease in message abundance caused by the expression of antisense C/EBP RNA was the result of a decrease in the rate of transcription of the C/EBP and 422(aP2) genes, nuclear run-on transcription experiments were performed. Accordingly, nuclei were isolated from control (i.e., untransfected and pBCMGNeo-transfected cells) and pBCMGAS-transfected 3T3-L1 cells on days 3 and 5 after the cells had been subjected to the differentiation protocol. As shown in Figure 6, the amounts of both transcripts formed dur-

Table 1. Estimated copy number of chromosomal and extrachromosomal sense and antisense plasmids in transfected cell lines

\begin{tabular}{|c|c|c|c|c|}
\hline \multirow[b]{2}{*}{$\begin{array}{l}\text { Cell } \\
\text { line }\end{array}$} & \multicolumn{2}{|c|}{$\begin{array}{c}\text { Low-molecular-weight } \\
\text { (extrachromosomal) } \\
\text { DNA }\end{array}$} & \multicolumn{2}{|c|}{$\begin{array}{c}\text { High-molecular-weight } \\
\text { (chromosomal) } \\
\text { DNA }\end{array}$} \\
\hline & $\begin{array}{l}\text { antisense } \\
\mathrm{C} / \mathrm{EBP}\end{array}$ & $\begin{array}{l}\text { sense } \\
\text { C/EBP }\end{array}$ & $\begin{array}{l}\text { antisense } \\
\mathrm{C} / \mathrm{EBP}\end{array}$ & $\begin{array}{l}\text { sense } \\
\text { C/EBP }\end{array}$ \\
\hline ASl & $\geqslant 5$ & - & 4 & - \\
\hline Rev 1 & $\leqslant 5$ & $\geqslant 20$ & 1 & 3 \\
\hline Rev 2 & $\leqslant 5$ & $\leqslant 5$ & 0 & 1 \\
\hline Rev 3 & $\leqslant 5$ & $\leqslant 5$ & 2 & 4 \\
\hline $\mathrm{AS} 2$ & $\geqslant 4$ & - & 10 & - \\
\hline AS3 & $\geqslant 8$ & - & 9 & - \\
\hline Rev 4 & $\geqslant 8$ & $\geqslant 8$ & 9 & 21 \\
\hline
\end{tabular}

Quantitation of the copy number of extrachromosomal and chromosomal pBCMGAS in AS cell lines was performed by densitometry of the autoradiograph shown in Fig. 2, using a known amount of pBCMGAS as standard. Similarly, low- and highmolecular-weight DNA from the revertant cell lines was digested either with $X$ hoI, which revealed both the $\sim 0.4 \mathrm{~kb}$ sense and antisense C/EBP fragments, or with BamHI and HindIII, which revealed a $0.96-\mathrm{kb}$ fragment including $\sim 0.4 \mathrm{~kb}$ of the sense C/EBP insert and $0.56 \mathrm{~kb}$ of the poly $\mid \mathrm{A})^{+}$-containing segment of rabbit $\beta$-globin present in the vector. The copy number of pBCMGAS was calculated from the sum of the copy number of pBCMGS and pBCMGAS (quantitated from the signals of the $\sim 0.4-\mathrm{kb} X$ hoI fragments) minus the copy number of pBCMGS (quantitated from the signals of the 0.96-kb BamHI-HindIII fragment). 
A
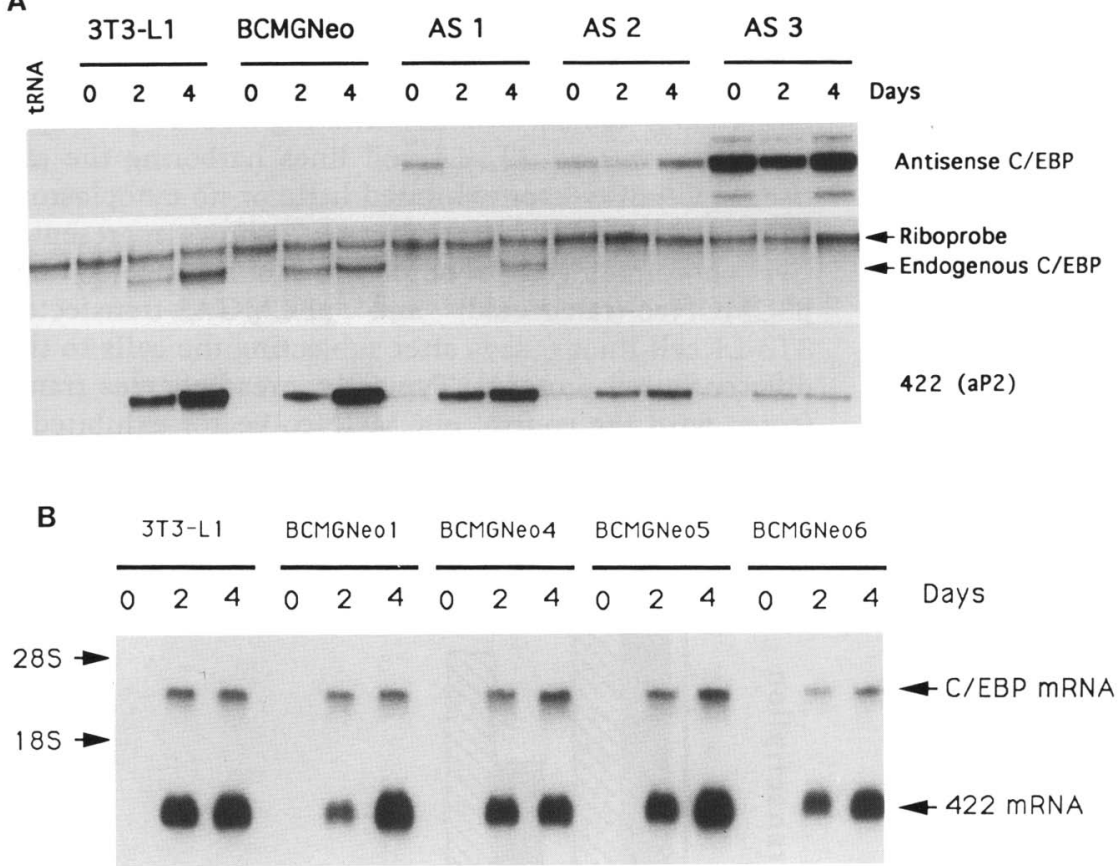

Figure 3. Expression of antisense C/EBP RNA, C/EBP mRNA, and 422(aP2) mRNA in 3T3-L1 cells harboring the pBCMGAS antisense expression vector. $(A)$ The 3T3L1, BCMGNeo (i.e., BCMGNeo control cell line; see Fig. 3B), and antisense (AS1, AS2, and AS3) cells lines were subjected to the differentiation protocol (see Materials and methods). Total RNA was isolated on day 0,2 , and 4 of induction of differentiation and subjected to RNase protection analysis. Total RNA (10 $\mu \mathrm{g})$ was hybridized with riboprobes specific for antisense C/EBP RNA, endogenous C/EBP mRNA, and $422(\mathrm{aP} 2) \mathrm{mRNA}$ overnight at $54^{\circ} \mathrm{C}$ and treated with RNase $A$ and $T_{1}$. The protected radiolabeled fragments were subjected to electrophoresis on a sequencing gel. The protected segments of antisense C/EBP RNA, endogenous C/EBP mRNA, and $422(\mathrm{aP} 2)$ mRNA correspond to the 220-bp HincII-MluI fragment of C/EBP cDNA, the 280-bp SmaI-SacI fragment of C/EBP cDNA, and the 270-bp HindIII-Sall fragment of $422(\mathrm{aP2}) \mathrm{cDNA}$, respectively. (B) Total RNA isolated from the control 3T3-L1 and BCMGNeo cell lines was isolated on day 0, 2, and 4 of differentiation. Total RNA (20 $\mu$ g) was denatured with glyoxal followed by electrophoresis on a $1 \%$ agarose gel. The Northern blot was prepared and hybridized with probes specific for C/EBP mRNA and $422(\mathrm{aP} 2)$ mRNA.

ing run-on transcription were markedly reduced in cells that express antisense C/EBP RNA (i.c., AS1, AS2, and AS3 cells) compared with control cells. As might be anticipated if C/EBP is a transcriptional activator of the 422(aP2) gene, the extent of suppression of run-on transcription of this gene was generally greater than that of the C/EBP gene. Consistent with results showing that the greatest decrease in the cellular abundance of the 422(aP2) message occurred in cells expressing the highest levels of antisense C/EBP RNA, that is, AS3 and AS2 cells (see Fig. 3A), the suppression of run-on transcription of the 422(aP2) gene was most marked in AS3 and AS2 cells (Fig. 6).
Effect of expression of antisense C/EBP RNA on the rate of cell proliferation and cytoplasmic triglyceride accumulation

After induction of differentiation, confluent 3T3-L1 preadipocytes undergo two to three rounds of mitosis, become quiescent, and then coordinately express the set of enzymes and proteins responsible for de novo cytoplasmic triglyceride synthesis (Mackall et al. 1976; Coleman et al. 1978; Bernlohr et al. 1985). Expression of C/EBP mRNA begins as preadipocytes reenter the quiescent state just before the onset of cytoplasmic triglyceride accumulation (Birkenmeier et al. 1989; Christy et al.

A

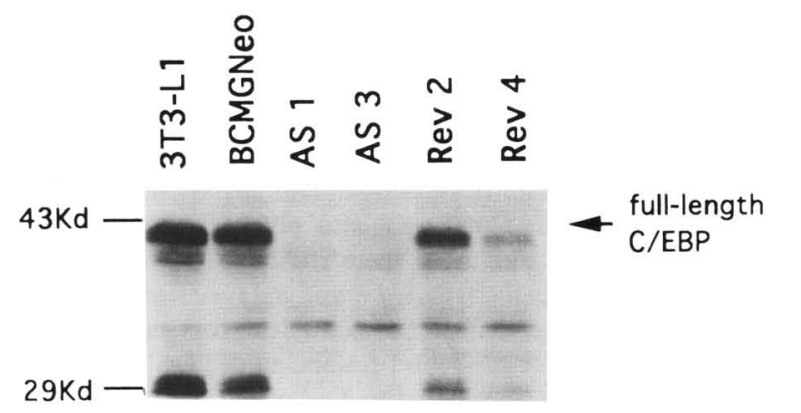

B

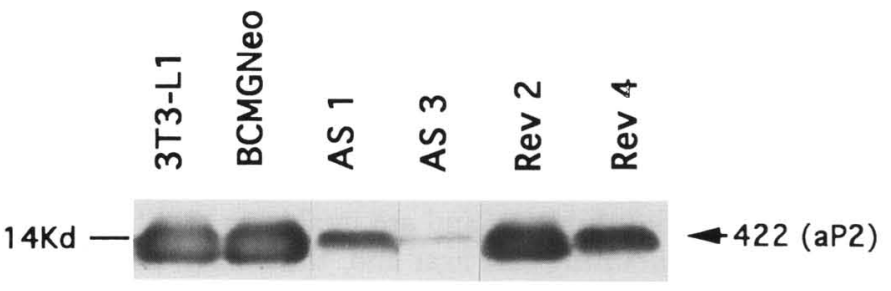

Figure 4. Expression of C/EBP and 422(aP2) proteins. 3T3-L1, BCMGNeo (i.e., BCMGNeo control cell line; see Fig. 3B), antisense (AS1 and AS3), and revertant (Rev 2 and Rev 4) cell lines were subjected to the differentiation protocol (see Materials and methods). After cell lysis, $250 \mu \mathrm{g}$ of cellular protein was subjected to SDS-polyacrylamide gel electrophoresis and Western blot analysis. $(A)$ Western blot analysis of C/EBP with a primary antibody directed against a peptide corresponding to amino acid residues 253-265 of C/EBP. (B) Western blot analysis of $422(\mathrm{aP} 2)$ protein using an antibody directed against a peptide corresponding to the 14 carboxy-terminal amino acids of $422(\mathrm{aP} 2)$ protein. 


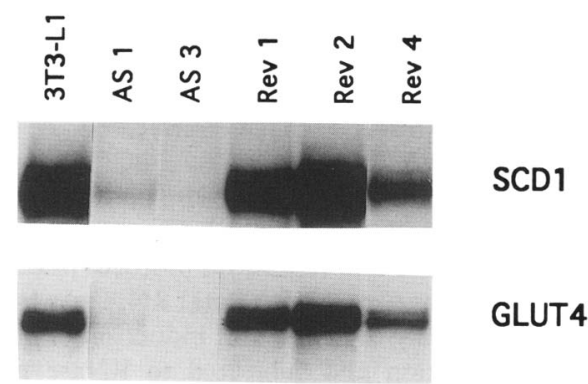

Figure 5. Expression of GLUT4 and SCD1 mRNA. Total RNA $(10 \mu \mathrm{g})$ from the control 3T3-L1, ASl, AS3, and revertant cell lines (Rev 1, Rev 2, and Rev 4) was subjected to RNase protection analysis using sequence-specific riboprobes for GLUT4 and SCD1 mRNAs. The protected regions of GLUT4 and SCD1 mRNA correspond to a 180-bp EcoRI-Smal fragment of GLUT4 cDNA and a 160-bp EcoRI-PstI fragment of SCDl cDNA, respectively.

1989). Recent evidence has shown that C/EBP is antimitogenic (Umek et al. 1991) and, thus, may be responsible for entry of preadipocytes into the quiescent terminally differentiated state. Experiments were undertaken to determine whether inhibition of expression of $\mathrm{C} / \mathrm{EBP}$ in 3T3-L1 cells harboring the antisense C/EBP expression vector affected their doubling time, morphology, and ability to accumulate cytoplasmic triglyceride when induced to differentiate.

Comparison of the rates of proliferation during logarithmic growth of control 3T3-Ll preadipocytes and of preadipocytes transfected with the pBCMGNeo or pBCMGAS (AS1, AS2, and AS3 cells) vectors revealed no significant changes. In several experiments the doubling times for these cell lines were indistinguishable, averaging 16-17 hr (results not shown). Perhaps this is not surprising, as proliferating 3T3-Ll preadipocytes do not express a detectable level of C/EBP mRNA (Birkenmeier et al. 1989; Christy et al. 1989|. Upon achieving growth arrest $\sim 2$ days after confluence $\left(6 \times 10^{6}\right.$ to $8 \times 10^{6}$ cells $/$ 10-cm culture dish); however, 3T3-L1 preadipocytes and pBCMGNeo-transfected 3T3-L1 preadipocytes express an extremcly low, but detectable, level of C/EBP message (Christy et al. 1989 and data not shown). We have observed repeatedly that $3 \mathrm{~T} 3-\mathrm{L} 1$ preadipocytes harboring the pBCMGAS vector, which do not express a detectable level of C/EBP mRNA, require slightly more time $\mid \sim 3$ days after confluence) to achieve grow th arrest and, upon doing so, exhibit a somewhat higher cell density $1 \sim 10^{7}$ cells $/ 10-\mathrm{cm}$ culture dish). It should be noted, however, that, like 3T3-Ll preadipocytes, cell lines harboring the pBCMGNeo or pBCMGAS vectors exhibit density-dependent growth inhibition and are unable to proliferate in medium containing soft agar and, thus, have not acquired characteristics typical of transformed cells /results not shown).

Normally, the accumulation of cytoplasmic triglyceride droplets can be detected on day 3 after the induction of differentiation of 3T3-L1 preadipocytes (Student et al. 1980). Although in some pBCMGNeo-transfected con- trol cell lines the onset of triglyceride accumulation was slightly delayed, by day 4 all lines exhibited the accumulation of cytoplasmic triglyceride and the spherical morphology typical of differentiating 3T3-L1 preadipocytes. In contrast, 3T3-L1 cell lines harboring the antisense C/EBP vector exhibited little or no cytoplasmic triglyceride accumulation. Figure 7 shows representative photomicrographs of control /untransfected and pBCMGNeo-transfected) and pBCMGAS-transfected 3T3-L1 cell lines 6 days after subjecting the cells to the differentiation protocol. Typically, preadipocytes transfected with the control pBCMGNeo vector exhibited a
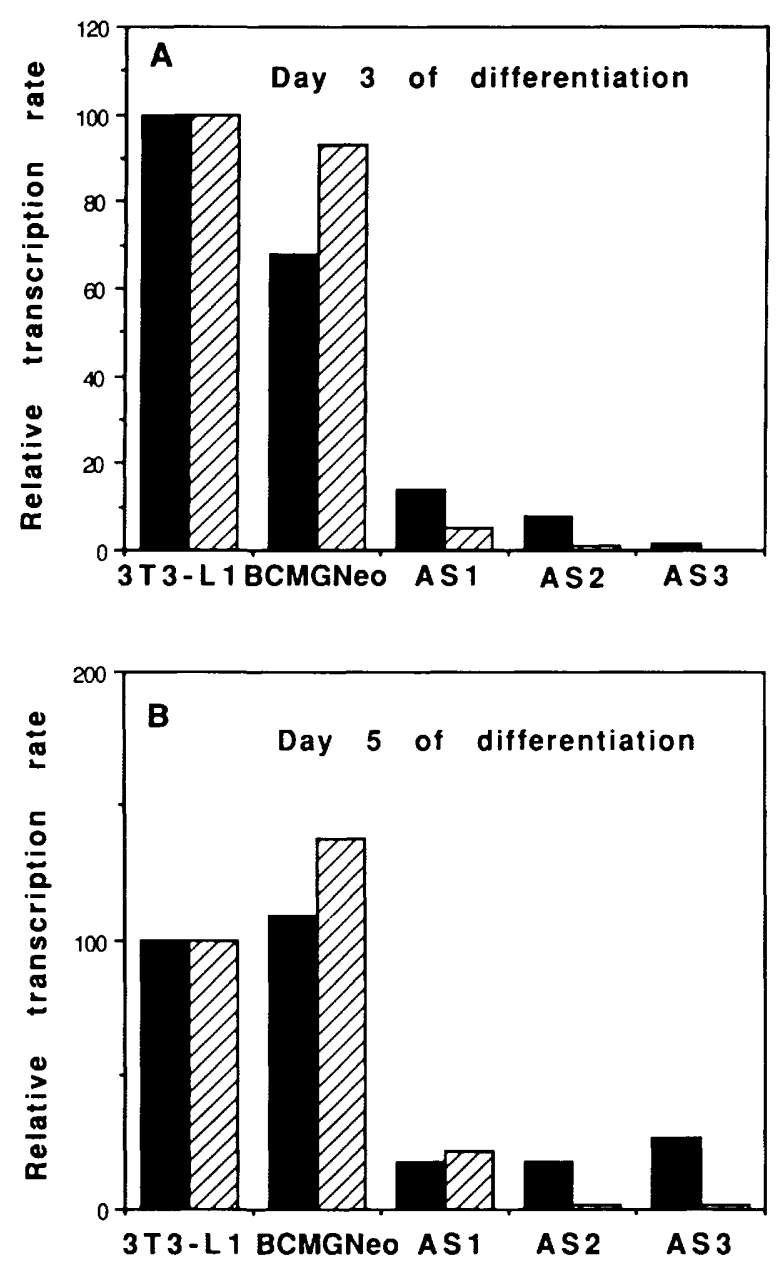

Figure 6. Rates of run-on transcription of the C/EBP and $422(\mathrm{aP} 2)$ genes by nuclei from control and antisense cell lines. Control (3T3-Ll and BCMGNeo) and pBCMGAS-transfected cell lines (AS1, AS2, and AS3) were induced to differentiate. Nuclei from $3 \times 10^{7}$ cells, isolated 3 and 5 days after induction of differentiation, were subjected to nuclear run-on transcription assays using $\left[\alpha-{ }^{32} \mathrm{P}\right]$ UTP and unlabeled NTPs. The ${ }^{32} \mathrm{P}$-labeled transcripts were hybridized to $2 \mu \mathrm{g}$ of a 280-bp SmaI-SacI fragment of the C/EBP cDNA (solid bars), $2 \mu \mathrm{g}$ of a linearized plasmid containing 270-bp of the 422(aP2) (hatched bars) cDNA, and $100 \mathrm{ng}$ of 3T3-L1 genomic DNA by slot blotting. Quantitation of the run-on transcripts was performed by densitometry of autoradiograms normalized to radiolabeled transcripts hybridized to 3T3-L1 genomic DNA. 
somewhat reduced extent of adipose conversion than untransfected 3T3-L1 preadipocytes. This loss of potential to differentiate is typical of 3T3-L1 preadipocytes carried through the rigors of procedures used in selecting G418resistant foci.

In contrast to control cells, cell lines harboring the pBCMGAS vector, such as, ASl and AS3 cells, which express antisense C/EBP RNA (see Fig. 3A), gave rise only to occasional cells that exhibited cytoplasmic triglyceride. This is true even when these cells were carried in culture for 2 weeks after the induction of differentiation. This finding supports the view that C/EBP is required for the expression of proteins involved in the process of triglyceride synthesis or deposition, or both, during preadipocyte differentiation. It was reported recently (Samuelsson et al. 1991) that transfection of an antisense C/EBP RNA expression vector into 3T3-F442A cells caused decreased expression of C/EBP mRNA and a reduced ability to accumulate cytoplasmic lipid droplets.

Reversal of antisense C/EBP RNA-suppressed gene expression and triglyceride accumulation by transfection with a sense C/EBP RNA expression vector

To verify that the process of transfecting $3 \mathrm{~T} 3-\mathrm{L} 1$ preadipocytes with the antisense C/EBP expression vector had not irreversibly and nonspecifically damaged their capac- ity to differentiate into adipocytes, we sought to reverse the loss of the "adipocyte phenotype" by transfecting AS cells with a sense C/EBP RNA expression vector. Therefore, a vector (pBCMGS) was constructed that directs the expression of a sense C/EBP RNA $(\sim 400$ bases of C/EBP RNA complementary to those directed by pBCMGAS) and would hybridize to the antisense RNA encoded by the pBCMGAS vector. It was our expectation that transfection and overexpression of the vector-derived sense C/EBP RNA in cell lines harboring the pBCMGAS vector would neutralize the antisense C/EBP RNA and possibly restore the adipocyte phenotype.

The pBCMGS vector (see Fig. 1B) contains both the $\sim 400$-bp HincII-SmaI segment of the C/EBP cDNA in the sense orientation and a hygromycin- $\mathrm{B}$ resistance gene (Gritz and Davies 1983) under the control of the HSV-1 thymidine kinase gene promoter (Sugden et al. 1985) permitting selection of stable cell lines. After transfection of the AS1, AS2, and AS3 cell lines (which already harbor the pBCMGAS vector) with the pBCMGS vector and selection with hygromycin, resistant cell lines were subjected to the differentiation protocol to identify revertants that express substantial amounts of cytoplasmic triglyceride. Of eight revertant cell lines obtained, four (Rev 1, Rev 2, Rev 3, and Rev 4 cells) were propagated for further study. In addition, several control cell lines (BCMGHyg 1, 2, and 3, derived from the AS1 and AS3 antisense cell lines), which harbor the vector
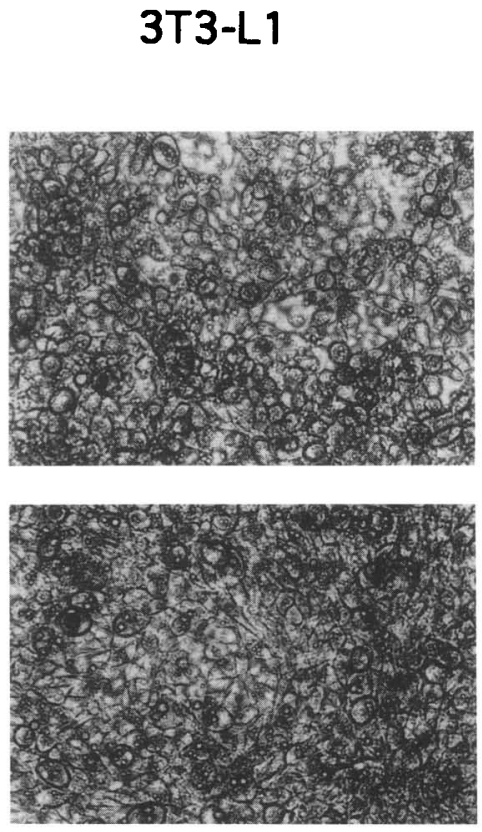

AS 1
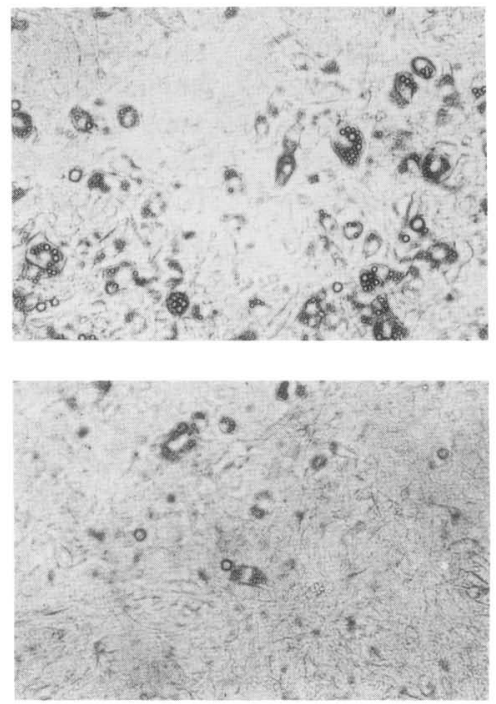

$\operatorname{Rev} 1$
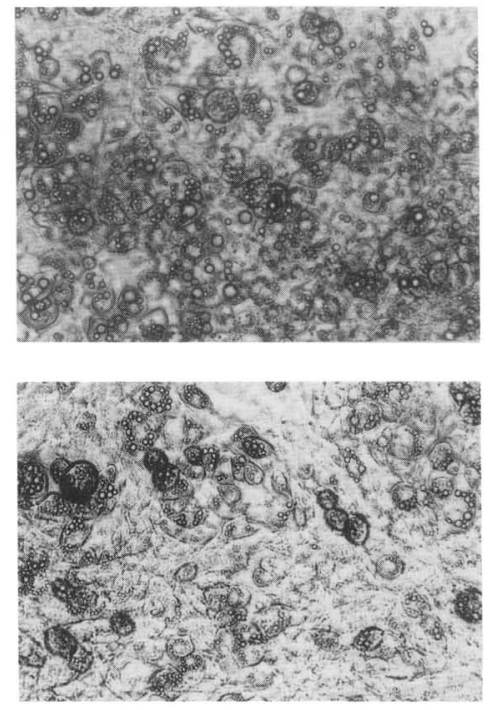

\section{BCMGNeo}

Rev 4

Figure 7. Cytoplasmic triglyceride accumulation. Six days after induction of differentiation, cells were photographed by phasecontrast microscopy. 3T3-L1 and BCMGNeo control cells (80-95\%) expressed cytoplasmic triglyceride, whereas $15-20 \%$ and $<5 \%$ of the antisense cell lines, ASI and AS3, respectively, exhibited triglyceride accumulation. Revertant cell lines Rev $1(70-80 \%)$ and Rev $5(30-40 \%)$ harboring both the pBCMGAS and the pBCMGS vectors, respectively, expressed cytoplasmic triglyceride. These findings are representative of results with several other AS and Rev cell lines. 
containing the hygromycin resistance gene, but lack the sense C/EBP cDNA insert, were selected for study.

Southern blots (not shown) performed on low-molecular-weight DNA isolated from the revertant cell lines revealed that all four revertant lines possessed multiple, that is, $5-20$, copies of the transfected $\sim 400$-bp sense $\mathrm{C} / \mathrm{EBP}$ sequence in extrachromosomal vector DNA /see Table 1). As observed with the pBCMGAS vector, integrated copies of the $\mathrm{pBCMGS}$ vector in chromosomal DNA were also detected after multiple passages of the cell lines. The revertant cell lines possessed from 1 to 21 integrated copies of the transfected $\sim 400$-bp sense $\mathrm{C} / \mathrm{EBP}$ sequence per cell in addition to multiple copies of the $\sim 400$-bp antisense C/EBP sequence (see Table 1). The extent to which reversion to the adipocyte phenotype occurs would be expected to depend on the relative levels of expression of the sense and antisense RNAs that would differ for each cell line.

The four revertant cell lines (Rev 1, Rev 2, Rev 3, and Rev 4 cells), which accumulate cytoplasmic triglyceride when subjected to the differentiation protocol, were subjected to more detailed analysis. Each of these cell lines was found to express vector-encoded sense C/EBP RNA (Fig. 8A,B), which accounts for the marked reduction or virtual elimination of its complementary antisense C/EBP RNA (Fig. 8A,B). That the antisense C/EBP RNA had caused the decrease in level of endogenous C/EBP mRNA in the AS cell lines (see Fig. 3A) is indicated by the recovery of expression of this message and of 422(aP2) mRNA in the revertant cells (Rev 1, Rev 2, Rev 3 , and Rev 4 cells), which express the exogenous sense C/EBP RNA (Fig. 8A,B). As with the mRNAs, decreased expression of C/EBP and 422(aP2) proteins caused by antisense C/EBP RNA was also reversed by overexpression of sense C/EBP RNA (see Fig. 4A,B). This interpretation is strengthened by the finding that the levels of two other messages (i.e., SCD1 and GLUT4 mRNAs), both of which were repressed by antisense C/EBP RNA, also return to near control levels in revertant cell lines expressing exogenous sense C/EBP RNA (see Fig. 5). Taken to- gether, these findings are consistent with previous observations showing that $\mathrm{C} / \mathrm{EBP}$ is capable of transactivating reporter gene expression driven by the promoters of the $422(\mathrm{aP2}), \mathrm{SCD} 1$, and GLUT4 genes (Christy et al. 1989; Kaestner et al. 1990).

The deposition of cytoplasmic triglyceride is another phenotypic characteristic of adipocytes that is lost in AS cells expressing antisense C/EBP RNA (see above). Shown in Figure 7 are representative photomicrographs of control (3T3-Ll and pBCMGNeo-transfected) cells, of cells (AS1 and AS3 cells) harboring the pBCMGAS antisense C/EBP vector, and of revertant cells (Rev 1 and Rev 4 cells/ harboring both the pBCMGAS antisense $\mathrm{C} / \mathrm{EBP}$ and $\mathrm{pBCMGS}$ sense $\mathrm{C} / \mathrm{EBP}$ vectors. It is evident that the suppression of triglyceride accumulation in ASl and AS3 cells caused by the pBCMGAS (antisense) vector was reversed by subsequent transfection of these cells with the pBCMGS (sense) vector.

It should be noted that transfection of the ASl and AS3 cell lines with the pBCMGHyg vector did not give rise to any "revertant" cell lines. Of 30 cell lines harboring both pBCMGAS and pBCMGHyg vectors, none exhibited the reverted adipocyte phenotype.

\section{Discussion}

This investigation shows unequivocally that expression of a partial ( 400-bp) antisense C/EBP RNA can decrease cellular C/EBP mRNA level by $95-98 \%$. The principal mechanism by which $\mathrm{C} / \mathrm{EBP}$ message level is decreased is through a reduced rate of transcription of the C/EBP gene (Fig. 6). It is not obvious how expression of an antisense C/EBP RNA might inhibit the transcription of its own gene. Hybridization of antisense RNA to nascent or completed C/EBP pre-mRNA transcripts would not be expected a priori to block initiation of transcription or subsequent run-on transcription of the C/EBP gene. A possible explanation derives from our earlier finding (Christy et al. 1991) that C/EBP itself can bind to the promoter of the C/EBP gene, raising the possibility that
Figure 8. Expression of endogenous $\mathrm{C} / \mathrm{EBP}$ and 422(aP2) mRNAs and exogenous sense and antisense C/EBP RNAs in revertant cell lines harboring both pBCMGAS and pBCMGS. (A) Revertant cell lines Rev 1, Rev 2, and Rev 3 were derived by transfecting pBCMGS into the AS1 cell line. Six days after inducing differentiation, $10 \mu \mathrm{g}$ of total RNA from 3T3-L1, ASl, and Rev 1, Rev 2, and Rev 3 cells was subjected to RNase protection analysis. The protected segment of exogenous sense C/EBP RNA corresponds to the 160-bp MluI-SmaI fragment of C/EBP cDNA. The other protected fragments are the same as described in Fig. 3A. $|B|$ Revertant cell line Rev 4 was derived by transfecting pBCMGS into the AS3 cell line. Six days after inducing differentiation, $10 \mu \mathrm{g}$ of total RNA from 3T3-L1, AS3, and Rev 4 cells was analyzed by RNase protection. The protected segments of the target RNAs were the same as described in $A$.
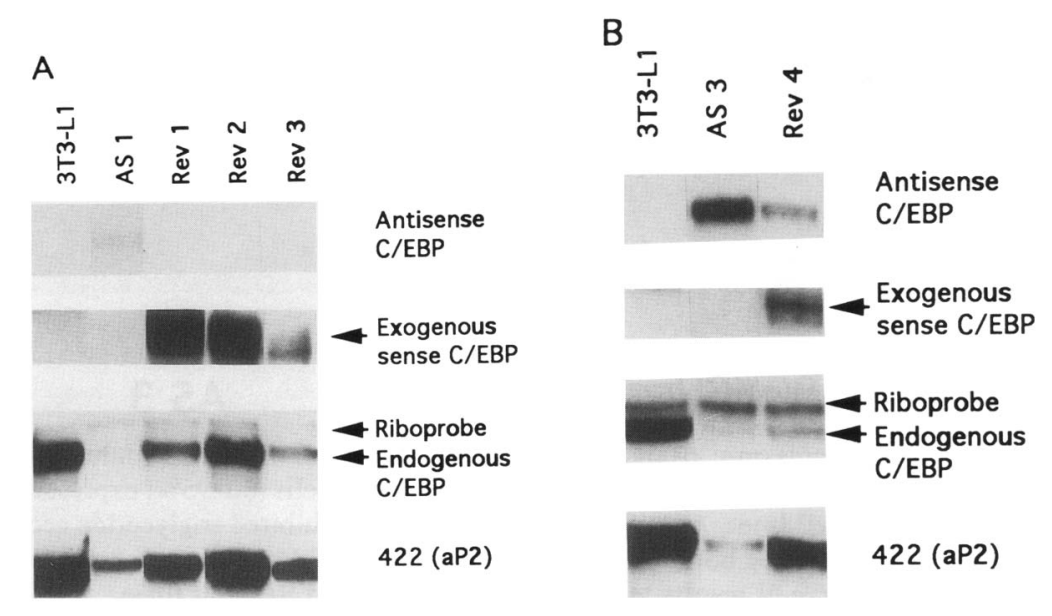
this transcription factor may autoactivate transcription of its own gene. Were this the case, inhibition by antisense C/EBP RNA of a post-transcriptional event (e.g., accelerated turnover of C/EBP mRNA or inhibition of translation of C/EBP mRNA) might indirectly reduce, but not completely block, transcription of the C/EBP gene. Supporting this hypothesis is the fact that run-on transcription of the C/EBP gene was repressed by $73 \%$ in AS3 cells expressing antisense C/EBP RNA (Fig. 6B), whereas run-on transcription of the $422(\mathrm{aP} 2)$ gene (Fig. $6 \mathrm{~B})$ and steady-state levels of $422(\mathrm{aP} 2)$ mRNA (Fig. 3B) were reduced to a much greater extent, that is, by $98.5 \%$, in AS3 cells.

In support of the hypothesis that C/EBP /or another protein that interacts with the C/EBP-binding site in the promoter of the C/EBP gene/ may regulate transcription of its own gene is suggested by DNase I footprinting of the promoter of the gene. The region between nucleotide -203 and -176 exhibits different, but overlapping, footprints by factors present in nuclei from differentiated and undifferentiated 3T3-L1 cells (Christy et al. 1991). We have observed that nuclear extracts from AS3 cells (subjected to the differentiation protocol), which express high levels of antisense C/EBP RNA (Fig. 3A), footprint the region between nucleotides -203 and -176 in a manner identical to extracts from wild-type $3 \mathrm{~T} 3-\mathrm{L} 1$ preadipocytes, but differently from those of differentiated 3T3-L1 adipocytes (results not shown). It should be noted that LAP or C/EBP $\beta$ (Descombes et al. 1990; Cao et al. 1991) and C/EBPS (Cao et al. 1991) are also capable of binding at the same sites at which C/EBP binds (Descombes et al. 1990; Williams et al. 1991). Thus, at present, we cannot rule out the possibility that altering expression of $\mathrm{C} / \mathrm{EBP} \alpha$ using the antisense RNA approach alters the expression of other transcription factors which, in turn, interact with the promoters of the $\mathrm{C} / \mathrm{EBP} \alpha, 422(\mathrm{aP2}), \mathrm{SCD} 1$, and GLUT4 genes.

Specificity was a major consideration in the choice of a C/EBP CDNA sequence to incorporate into the antisense C/EBP expression vector. An attempt was made to avoid using sequences corresponding to the basic and leucine zipper domains of $\mathrm{C} / \mathrm{EBP}$, as these regions have a high degree of nucleotide sequence identity to several other transcription factors, namely LAP (Descombes et al. 1990; NF-IL6, Akira et al. 1990; IL-6 DBP, Poli et al. 1990; AGP/EBP, Chang et al. 1990; C/EBP 3 , Cao et al. 1991; CRP2, Williams et al. 1991), Ig/EBP-1 (Roman et al. 1990), CRP1 (Williams et al. 1991), CELF (Kageyama et al. 1991; CRP3, Williams et al. 1991; C/EBP8, Cao et al. 1991). Hence, the $\sim 400$-bp segment of the C/EBP cDNA (between the HincII and SmaI sites in cDNA p6A1, Fig. 1A) that lies $5^{\prime}$ to the basic DNA-binding and leucine zipper dimerization domains was selected. A computer search of the GenBank rodent sequence library revealed no other nucleotide sequences with significant identity.

It appeared, therefore, that the expression of antisense C/EBP RNA directed by the pBCMGAS vector that contains the $\sim 400$-bp antisense sequence would specifically hybridize to endogenous C/EBP mRNA. RNase protec- tion analysis revealed that pBCMGAS-directed expression of antisense C/EBP RNA suppressed the level of endogenous C/EBP mRNA (Figs. 3A and 4) without lowering the level of LAP mRNA (results not shown).

Of interest is the fact that expression of antisense C/EBP RNA in 3T3-L1 preadipocytes had no detectable effect on cell proliferation rate. Hence, the doubling time of control (3T3-Ll and pBCMGNeo-transfected cells) and pBCMGAS-transfected cells was the same, that is, 16-17 hr. The laboratory of S. McKnight (Umek et al. 1991) has provided compelling evidence that C/EBP is antimitogenic. This finding is compatible with the fact that C/EBP mRNA (1) is not detected in logarithmically dividing 3T3-L1 preadipocytes, $(2)$ is expressed at extremely low levels in confluent 3T3-L1 preadipocytes, and $(3)$ is expressed at high levels only upon induction of differentiation of 3T3-L1 preadipocytes into adipocytes (Christy et al. 1989). Because expression of antisense C/EBP RNA, which effectively blocks expression of C/EBP mRNA and the acquisition of the adipocyte phenotype, has no detectable effect on mitosis, it is evident that $\mathrm{C} / \mathrm{EBP}$ is not involved in the proliferative phase of the cell cycle. Rather, C/EBP may function by suppressing cell division as cells, such as 3T3-Ll preadipocytes, enter the quiescent terminally differentiated state.

The participation of C/EBP in differentiation-activated cxpression of the $422(\mathrm{aP} 2)$ gene in preadipocytes was questioned recently by B.M. Spiegelman and co-workers (Graves et al. 1991). These investigators discovered a strong upstream enhancer of the $422(\mathrm{aP2})$ gene that is capable of directing adipose-specific expression in transgenic mice. It was observed that a transgene containing the enhancer, but lacking the region of the $422(\mathrm{aP} 2)$ gene promoter containing the C/EBP-binding site and an overlapping negative regulatory element, retains the ability to direct adipose-specific expression. Investigations in our laboratory (Yang et al. 1989; Cheneval et al. 1991) suggest that C/EBP may be involved in the mechanism by which the negative regulatory element in the $422(\mathrm{aP} 2)$ gene promoter is derepressed during differentiation. Therefore, promoter constructs containing the enhancer, but lacking both the C/EBP-binding site and the overlapping negative regulatory element, might be expected to be constitutively active. Further work will be needed to determine whether and if so, by what mechanism, the negative regulatory element in the $422(\mathrm{aP} 2)$ gene promoter can override the effect of the adipose-specific enhancer before differentiation and the expression of C/EBP. We have observed (F.-T. Lin and M.D. Lane, unpubl.) that an extremely low level of 422(aP2) mRNA can be detected by RNase protection analysis in confluent, but not proliferating, 3T3-L1 preadipocytes before differentiation. This low level of $422(\mathrm{aP} 2)$ message correlates well with the extremely low level of C/EBP message present in confluent 3T3-L1 preadipocytes and its absence in dividing preadipocytes.

\section{Materials and methods}

Plasmid construction

The 14.8-kb pBCMGNeo expression vector was derived by re- 
moving the mouse IL-2 cDNA insert from the Xhol site of pBCMGNeo $\cdot$ mIL-2, which was a gift from Dr. Hajime Karasuyama (Karasuyama et al. 1989). A segment of the C/EBP cDNA extending from nucleotide +490 to the poly $(\mathrm{A})^{+}$tail, previously designated p6A-1 (Christy et al. 1991), was subcloned into the EcoRI site of pBluescript. After digestion with HincII and SmaI, the gel-purified $\sim 0.4-\mathrm{kb}$ C/EBP fragment was ligated with $X$ hoI linkers and inserted into the XhoI site of pBCMGNeo in the sense or antisense orientations, which was confirmed by DNA sequencing (Sanger et al. 1977). The antisense C/EBP plasmid was designated pBCMGAS. A 2.5-kb hygromycin resistance gene from plasmid $\mathrm{pBHPH}$, a gift from $\mathrm{Dr}$. David Weng, was inserted into the XbaI site of the sense C/EBP plasmid, now designated pBCMGS, as a second marker for selecting stable cell lines harboring both pBCMGS and the antisense pBCMGAS construct. The control plasmid, pBCMGHyg, was derived by removing the $\sim 0.4-\mathrm{kb}$ sense C/EBP fragment from the XhoI site of pBCMGS.

\section{Stable transfection by electroporation}

Thirty percent confluent, low passage 3T3-Ll preadipocytes were transfected with $5 \mu \mathrm{g}$ of the antisense C/EBP plasmid, pBCMGAS, or control vector, $\mathrm{pBCMGNeo,} \mathrm{by} \mathrm{electroporation}$ at $450 \mathrm{~V}$ with a capacitance of $25 \mu \mathrm{F}$, as described previously (Cook et al. 1988). After a 24 -hr recovery period, $350 \mu \mathrm{g} / \mathrm{ml}$ of G418 was added, and neomycin-resistant foci were isolated and propagated. Cells harboring the pBCMGAS vector were designated AS (antisense) cells.

Similarly, $20 \mu \mathrm{g}$ of the sense C/EBP plasmid, pBCMGS, or control vector, pBCMGHyg, was electroporated into $30 \%$ confluent AS cells maintained under G418 selection pressure 1300 $\mu \mathrm{g} / \mathrm{ml}$ of $\mathrm{G} 418$ for 1 week). Twenty-four hours after transfection, $150 \mu \mathrm{g} / \mathrm{ml}$ of hygromycin B was added, and hygromycinresistant foci were isolated and propagated.

\section{Cell culture and differentiation}

The 3T3-Ll preadipocytes were maintained in Dulbecco's modified Eagle medium (DMEM) with $10 \%$ calf serum. Differentiation was induced by treating 2 -day postconfluent cells (designated day 0 ) with $10 \%$ fetal bovine serum, $1 \mu \mathrm{g} / \mathrm{ml}$ of insulin, 1 $\mu \mathrm{M}$ dexamethasone, and $0.5 \mathrm{~mm} 3$-isobutyl-1-methylxanthine as described (Reed and Lane 1980; Student et al. 1980). The medium was then replaced, and cells were fed every other day with DMEM supplemented with only insulin and $10 \%$ FBS. The appearance of cytoplasmic triglyceride droplets as the cells differentiated into adipocytes was visualized by staining with OilRed-O (Preece 1972).

\section{Radiolabeled probes}

DNA probes for Northern and Southern blot analyses were labeled by the random hexamer-priming method (Feinberg and Vogelstein 1983). The 422(aP2) hybridization probe was the fulllength cDNA (Bernlohr et al. 1984). The hybridization probe for endogenous and exogenous sense or antisense C/EBP DNAs and RNAs was the $\sim 0.4-\mathrm{kb}$ C/EBP insert of pBCMGAS, corresponding to nucleotides +490 to +870 of C/EBP cDNA.

The plasmid templates for synthesis of riboprobes for RNase protection analysis of C/EBP MRNA and exogenous sense and antisense C/EBP RNA were constructed by removing partial C/EBP sequences from p6A-1 using appropriate restriction enzyme digestion and religation. The hybridization probes for 422|aP2|, GLUT4, and SCD1 mRNAs were prepared by cloning a sequence-specific cDNA fragment into the polylinker cloning sites of pGEM. The riboprobes were generated using $1 \mu \mathrm{g}$ of linearized plasmid templates, $\left[\alpha-{ }^{32} \mathrm{P}\right] \mathrm{CTP}$, and NTPs transcribed with bacteriophage T7 or T3 RNA polymerase in the antisense orientation (Melton et al. 1984).

\section{Isolation and analysis of DNA}

Low-molecular-weight DNA (including episomal vector DNA) from two $100-\mathrm{mm}$ dishes of confluent preadipocytes was prepared by the procedure of Hirt (1967). DNase-free RNase A at 20 $\mu \mathrm{g} / \mathrm{ml}$ was added to remove contaminating RNA followed by phenol/chloroform/isoamyl alcohol $(25: 24: 1)$ extraction and ethanol precipitation. High-molecular-weight-chromosomal DNA from one $100-\mathrm{mm}$ dish of confluent preadipocytes was isolated by the method of Wigler et al. (1979). Low-molecularweight DNA from two $100-\mathrm{mm}$ dishes, $20 \mu \mathrm{g}$ of high-molecularweight DNA, and plasmid DNAs were digested overnight with Xhol followed by electrophoresis on $0.7 \%$ agarose gels. After denaturation, neutralization, and transfer to Hybond membranes (Southern 1975), hybridization was performed with $10^{6}$ $\mathrm{cpm} / \mathrm{ml}$ of DNA probe as described (Ntambi et al. 1988). The copy number of integrated DNA was quantitated by densitometry of the autoradiograms and was normalized to the signals of restriction fragments of endogenous C/EBP derived from genomic DNA.

\section{Isolation and analysis of RNA}

Total RNA was isolated from 2-day postconfluent preadipocytes (day 0 of differentiation) and adipocytes after 2, 4, or 6 days of differentiation by the method of Chirgwin et al. (1979). For Northern blot analysis, $20 \mu \mathrm{g}$ of total RNA was denatured with glyoxal and dimethylsulfoxide and analyzed by electrophoresis on 1\% agarose gels as described (McMaster and Carmichael 1977; Thomas et al. 1980|. After transfer to Hybond membranes (Amersham) and UV cross-linking, the RNA blots were stained with methylene blue to locate $28 \mathrm{~S}$ and $18 \mathrm{~S}$ rRNAs and to verify loading. The blots were hybridized with $10^{6} \mathrm{cpm} / \mathrm{ml}$ of C/EBP and 422(aP2) DNA probes. Procedures for prehybridization and hybridization were the same as those for Southern analysis.

For RNase protection analysis, $2 \times 10^{5}$ to $5 \times 10^{5} \mathrm{cpm} / \mathrm{sam}$ ple of the riboprobe was hybridized overnight with $10 \mu \mathrm{g}$ of total RNA in $80 \%$ formamide at $54^{\circ} \mathrm{C}$. After RNase $A$ and $T_{1}$ treatment, the protected probe fragments, annealed to complementary sequences of the target RNA, were precipitated and analyzed on $6 \%$ polyacrylamide/7 $\mathrm{M}$ urea sequencing gels (Melton et al. 1984).

\section{Isolation of nuclei and nuclear run-on transcription analysis}

Isolation of nuclei from day 3 and day 5 differentiated cells was performed as described (Marzluff 1978). Nuclei from $3 \times 10^{7}$ cells were collected for nuclear run-on transcription assays using the protocol modified by Groudine et al. (1981). Transcripts from day 3 and day 5 differentiated cells $\left(1.74 \times 10^{7}\right.$ and $6.6 \times 10^{6} \mathrm{cpm} / \mathrm{ml}$ ) were hybridized to filter-bound cDNA in slot blots. Two micrograms of the 280-bp SmaI-SacI fragment of C/EBP cDNA, $2 \mu \mathrm{g}$ of linearized plasmid containing 270-bp HindIII-Sall fragment of $422(\mathrm{aP} 2 / \mathrm{cDNA}$, and $100 \mathrm{ng}$ of genomic DNA were denatured in $0.4 \mathrm{M} \mathrm{NaOH}$ and $10 \mathrm{mM}$ EDTA at $100^{\circ} \mathrm{C}$ for $10 \mathrm{~min}$ followed by neutralization with cold $2 \mathrm{M}$ ammonium acetate $(\mathrm{pH} 7)$, on ice. The denatured DNAs were applied to Hybond membranes (Amersham) using a Dot Blot apparatus. The procedures of prehybridization and hybridization were the same as those for Northern blots, except hybridization was for 4 days and treatment with RNase at $37^{\circ} \mathrm{C}$ for $30 \mathrm{~min}$ during 
washing. Run-on transcription rates were quantitated by densitometry of autoradiograms, and the signals were normalized to radioactive transcripts hybridized to $3 \mathrm{~T} 3-\mathrm{Ll}$ genomic DNA.

\section{Western blot analysis of $C / E B P$ and 422(aP2) proteins}

Five days after exposure to the differentiation protocol, cells were harvested and lysed with $1 \times$ lysis buffer containing $60 \mathrm{~mm}$ Tris (pH 6.8) and $1 \%$ SDS. The whole cell lysate was boiled for $5 \mathrm{~min}$. Cellular protein $(250 \mu \mathrm{g})$ was diluted in SDS-sample buffer and subjected to SDS-polyacrylamide gel electrophoresis (Laemmli 1970). After electrophoretic transfer to nitrocellulose, Ponceau-S staining was performed to ensure equal loading of each sample. $\mathrm{C} / \mathrm{EBP}$ and $422(\mathrm{aP} 2)$ proteins were detected using a rabbit antibody specific to an internal 14-amino-acid peptide (amino acid residues 253-265) of C/EBP (provided by Dr. P. Cornelius) or the carboxy-terminal 14 amino acids of 422 (aP2) protein (Bernlohr et al. 1984; provided by Dr. R.D. Hoffman). The membrane was then incubated with horseradish peroxidaseconjugated second antibody. The immunoreactive polypeptides were visualized by the ECL detection system (Amersham), following the procedures recommended by the supplier.

\section{Acknowledgments}

We thank Dr. R. Christy for providing C/EBP cDNA p6A-1; D. Geiman and T. Cheneval-Kastelic for technical advice; and P. Cornelius, A. Swick, and K. Landschulz for helpful advice. We are grateful to Dr. H. Karasuyama for providing the pBCMGNeo . mIL-2 vector and to Dr. D. Weng for providing the pBHPH (hygromycin resistance plasmid). We also thank Ms. Natalie Tumminia for her expert assistance in preparation of this manuscript. This work was supported by research grant NIDDK-38418 from the National Institutes of Health.

The publication costs of this article were defrayed in part by payment of page charges. This article must therefore be hereby marked "advertisement" in accordance with 18 USC section 1734 solely to indicate this fact.

\section{References}

Akira, S., H. Isshiki, T. Sugita, O. Tanabe, S. Kinoshita, Y. Nishio, T. Nakajima, T. Hirano, and T. Kishimoto. 1990. A nuclear factor for IL-6 expression (NF-IL6) is a member of a C/EBP family. EMBO /. 9: 1897-1906.

Bernlohr, D.A., C.W. Angus, M.D. Lane, M.A. Bolanowski, and T.J. Kelly Jr. 1984. Expression of specific mRNAs during adipose differentiation: Identification of an mRNA encoding a homologue of myelin P2 protein. Proc. Nat1. Acad. Sci. 81: 5468-5472.

Bernlohr, D.A., M.A. Bolanowski, T.J. Kelly Jr., and M.D. Lane. 1985. Evidence for an increase in transcription of specific mRNAs during differentiation of 3T3-Ll preadipocytes. $J$. Biol. Chem. 260: 5563-5567.

Birkenmeier, E.H., B. Gwynn, S. Howard, J. Jerry, J.I. Girdon, W.H. Landschulz, and S.L. McKnight. 1989. Tissue-specific expression, developmental regulation, and genetic mapping of the gene encoding CCAAT/enhancer binding protein. Genes \& Dev. 3: 1146-1156.

Boshart, M., F. Weber, G. Jahn, K. Dorsch-Hasler, B. Fleckenstein, and W. Schaffner. 1985. A very strong enhancer is located upstream of an immediate early gene of human cytomegalovirus. Cell 41: 521-530.

Cao, Z., R.M. Umek, and S.L. McKnight. 1991. Regulated expression of three C/EBP isoforms during adipose conversion of 3T3-L1 cells. Genes \& Dev. 5: 1538-1552.

Chang, C.-I., T.-T. Chen, H.-Y. Lei, D.-S. Chen, and S.C. Lee. 1990. Molecular cloning of a transcription factor, AGP/EBP, that belongs to members of the C/EBP gene family. Mol. Cell Biol. 10: 6642-6653.

Cheneval, D., R.J. Christy, D. Geiman, P. Cornelius, and M.D. Lane. 1991. Cell-free transcription directed by the 422 adipose P2 gene promoter: Activation by the CCAAT/enhancer binding protein. Proc. Natl. Acad. Sci. 88: 8465-8469.

Chirgwin, J.M., A.E. Przybyla, R.J. MacDonald, and W.J. Rutter. 1979. Isolation of biologically active ribonucleic acid from sources enriched in ribonuclease. Biochemistry 24:5294 5299.

Christy, R.J., V.W. Yang, J.M. Ntambi, D.E. Geiman, W.H. Landschulz, A.D. Friedman, Y. Nakabeppu, T.J. Kelly Jr., and M.D. Lane. 1989. Differentiation-induced gene expression in 3T3-Ll preadipocytes: CCAAT/enhancer binding protein interacts with and activates the promoters of two adipocytespecific genes. Genes \& Dev. 3: 1323-1335.

Christy, R.J., K.H. Kaestner, D.E. Geiman, and M.D. Lane. 1991. CCAAT/enhancer binding protein gene promoter: Binding of nuclear factors during differentiation of 3T3-Ll preadipocytes. Proc. Natl. Acad. Sci. 88: 2593-2597.

Coleman, R.A., B.C. Reed, J.C. Mackall, A.K. Student, M.D. Lane, and R.M. Bell. 1978. Selective changes in microsomal enzymes of triacylglycerol phosphotidylcholine, and phosphatidylethanolamine biosynthesis during differentiation. $J$. Biol. Chem. 253: 7256-7261.

Cook, K.S., C.R. Hunt, and B.M. Spiegelman. 1985. Developmentally regulated mRNA in 3T3-adipocytes: Analysis of transcriptional control. I. Cell. Biol. 100: 514-520.

Cook, J.S., J.J. Lucas, E. Sibley, M.A. Bolanowski, R.J. Christy, T. Kelly Jr., and M.D. Lane. 1988. Expression of the differentiation-induced gene for fatty-acid binding protein is activated by glucocorticoid and cAMP. Proc. Natl. Acad. Sci. 85: 2949-2953.

Descombes, P. and U. Schibler. 1991. A liver-enriched transcriptional activator protein, LAP, and a transcriptional inhibitory protein, LIP, are translated from the same mRNA. Cell 67: $569-579$.

Descombes, P., M. Chojkier, S. Lichtsteiner, E. Falvey, and U. Schibler. 1990. LAP, a novel member of the C/EBP gene family, encodes a liver-enriched transcriptional activator protein. Genes \& Dev. 4: 1541-1551.

DiMaio, D., R. Treisman, and T. Maniatis. 1982. Bovine papillomavirus vector that propagates as a plasmid in both mouse and bacterial cells. Proc. Natl. Acad. Sci. 79: 4930-4034.

Feinberg, A.P. and B. Vogelstein. 1983. A technique for radiolabeling DNA restriction endonuclease fragments to high specific activity. Anal. Biochem. 132: 6-13.

Graves, R.A., P. Tontonoz, S.R. Ross, and B.M. Spiegelman. 1991. Identification of a potent adipocyte-specific enhancer: Involvement of an NF-1-like factor. Genes. ef Dev. 5: 428437.

Green, H. and O. Kehinde. 1974. Sublines of mouse 3T3 cells that accumulate lipid. Cell 1: 113-116.

- 1975. An established preadipose cell line and its differentiation in culture. II. Factors affecting the adipose conversion. Cell 5: 19-27.

- _ 1976. Spontaneous heritable changes leading to increased adipose conversion in 3T3 cells. Cell 7: 105-113.

Gritz, L. and J. Davies. 1983. Plasmid-encoded hygromycin B resistance: The sequence of hygromycin $B$ phosphotransferase gene and its expression in Escherichia coli and Saccharomyces cerevisiae. Gene 25: 179-188.

Groudine, M., M. Peretz, and H. Weintraub. 1981. Transcrip- 
tional regulation of hemoglobin switching on chicken embryos. Mol. Cell. Biol. 1: 281-288.

Herrera, R., H.S. Ro, G.S. Robinson, K.G. Xanthopoulos, and B.M. Spiegelman. 1989. A direct role for C/EBP and the AP1 -binding site in gene expression linked to adipocyte differentiation. Mol. Cell. Biol. 9: 5331-5339.

Hirt, B. 1967. Selective extraction of polyoma DNA from infected mouse cell cultures. I. Mol. Biol. 26: 365-369.

Izant, J.G. and H. Weintraub. 1984. Inhibition of thymidine kinase gene expression by antisense RNA: A molecular approach to genetic analysis. Cell 36: 1007-1015.

Kaestner, K.H., J.M. Ntambi, T.J. Kelly Jr., and M.D. Lane. 1989. Differentiation-induced gene expression in 3T3-L1 preadipocytes: A second differentially-expressed gene encoding stearoyl-CoA desaturase. I. Biol. Chem. 264: 14755-14761.

Kaestner, K.H., R.J. Christy, and M.D. Lane. 1990. Mouse insulin-responsive glucose transporter gene: Characterization of the gene and trans-activation by the CCAAT/enhancer binding protein. Proc. Natl. Acad. Sci. 87: 251-255.

Kageyama, R., Y. Sasai, and S. Nakanishi. 1991. Molecular characterization of transcription factors that bind to the cAMP responsive region of the substance $\mathrm{P}$ precursor gene. $J$. Biol. Chem. 266: 15525-15531.

Karasuyama, H., N. Tohyama and T. Tada. 1989. Autocrine growth and tumorigenicity of interleukin 2-dependent helper $\mathrm{T}$ cells transfected with IL-2 gene. I. Exp. Med. 169: 13-25.

Kim, S.K. and B.J. Wold. 1985. Stable reduction of thymidine kinase activity in cells expressing high levels of antisense RNA. Cell 42: 129-138.

Knecht, D.A. and W.F. Loomis. 1987. Antisense RNA inactivation of myosin heavy chain gene expression in Dictyostelium discoideum. Science 236: 1081-1086.

Law, M.-F., D.R. Lowy, J. Dvoretzky, and P.M. Howley. 1981. Mouse cells transformed by bovine papilloma virus contain only extrachromosomal viral DNA sequences. Proc. Natl. Acad. Sci. 78: 2727-2731.

Laemmli, U.D. 1970. Cleavage of structural proteins during the assembly of the head of bacteriophage T4. Nature 227: 680685.

Lowy, D.R., J. Dvoretzky, R. Shaber, M.-F. Law, L. Engel, and P.M. Howley. 1980. In vitro tumorigenic transformation by a defined subgenomic fragment of bovine papilloma virus DNA. Nature 287: 72-74.

Mackall, J.C., A.K. Student, S.E. Polakis, and M.D. Lane. 1976. Induction of lipogenesis during differentiation in a preadipocyte cell line. J. Biol. Chem. 251: 6462-6464.

Marzluff, W.F. 1978. Transcription of RNA in isolated nuclei. Methods Cell Biol. 19: 317-331.

McMaster, G.K. and G.G. Carmichael. 1977. Analysis of single and double stranded nucleic acids on polyacrylamide and agarose gels by using glyoxal and acridine orange. Proc. Natl. Acad. Sci. 74: 4835-4838.

Melton, D.A., P.A. Krieg, M.R. Rebagliati, T. Maniatis, K. Zinn, and M.R. Green. 1984. Efficient in vitro synthesis of biologically active RNA and RNA hybridization probes from plasmids containing a bacteriophage SP6 promoter. Nucleic Acids. Res. 12: 7035-7056.

Melton, D.A. 1985. Injected anti-sense RNAs specifically block messenger RNA translation in vivo. Proc. Natl. Acad. Sci. 82: 144-148.

Ntambi, J.M., S.A. Buhrow, K.H. Kaestner, R.J. Christy, E. Sibley, T.J. Kelly Jr., and M.D. Lane. 1988. Differentiation-induced gene expression in 3T3-L1 preadipocytes. I. Biol. Chem. 263: 17291-17300.

Phillips, M., P. Djian, and H. Green. 1986. The nucleotide se- quence of three genes participating in the adipose differentiation of 3T3 cells. J. Biol. Chem. 261: 10821-10827.

Poli, V., F.P. Mancini, and R. Cortese. 1990. IL-6DBP, a nuclear protein involved in interleukin- 6 signal transduction, defines a new family of leucine zipper proteins related to C/EBP. Cell 63: 643-653.

Preece, A. 1972. Manual for histologic technicians. p. 260. Little, Brown, and Co., Boston, MA.

Reed, B.C. and M.D. Lane. 1980. Insulin receptor synthesis and turnover in differentiating 3T3-L1 preadipocytes. Proc. Natl. Acad. Sci. 77: 285-289.

Roman, C., J.S. Platero, J. Shuman, and K. Calame. 1990. Ig/ EBP-1: A ubiquitously expressed immunoglobulin binding protein that is similar to C/EBP and heterodimerizes with C/EBP. Genes \& Dev. 4: 1404-1415.

Rosen, O.M., C.J. Smith, A. Hirsch, E. Lai, and C.S. Rubin. 1979. Recent studies of the 3T3-L1 adipocyte-like cell line. Recent Prog. Horm. Res. 35: 477-499.

Samuelsson, L., K. Strömberg, K. Vikman, G. Bjursell, and S. Enerbäck. 1991. The CCAAT/enhancer binding protein and its role in adipocyte differentiation: Evidence for direct involvement in terminal adipocyte development. EMBO . 10: 3787-3793.

Sanger, F., S. Nicklen, and A.R. Coulson. 1977. DNA sequencing with chain-terminating inhibitors. Proc. Natl. Acad. Sci. 74: 5463-5467.

Sarver, N., P. Gruss, M-F. Law, G. Khoury, and P. Howley. 1981. Bovine papilloma virus deoxyribonucleic acid: A novel eucaryotic cloning vector. Mol. Cell. Biol. 1: 486-496.

Southern, E.M. 1975. Detection of specific sequences among DNA fragments separated by gel electrophoresis. I. Mol. Biol. 98: 503-517.

Student, A.K., R.Y. Hsu, and M.D. Lane. 1980. Induction of fatty acid synthetase synthesis in differentiating $3 \mathrm{~T} 3-\mathrm{L} 1$ preadipocytes. I. Biol. Chem. 255: 4745-4750.

Sugden, B., K. Marsh, and J. Yates. 1985. A vector that replicates as a plasmid and can be efficiently selected in B-lymphoblasts transformed by Epstein-Barr virus. Mol. Cell. Biol. 5: $410-413$.

Thomas, P.S. 1980. Hybridization of denatured RNA and small DNA fragments transferred to nitrocellulose. Proc. Natl. Acad. Sci. 77: 5201-5205.

Umek, R.M., A.D. Friedman, and S.L. McKnight. 1991. CCAAT-enhancer binding protein: A component of a differentiation switch. Science 251: 288-292.

Wigler, M., R. Sweet, G.K. Sim, B. Wold, A. Pellicer, E. Lacy, T. Maniatis, S. Silverstein, and R. Axel. 1979. Transformation of mammalian cells with genes from procaryotes and Eucaryotes. Cell 16: 777-785.

Williams, S.C., C.A. Cantwell, and P.F. Johnson. 1991. A family of C/EBP-related proteins capable of forming covalently linked leucine zipper dimers in vitro. Genes \& Dev. 5: 15531567.

Yang, V.W., R.J. Christy, J.S. Cook, T.J. Kelly, and M.D. Lane. 1989. Mechanism of regulation of the $422(\mathrm{aP2})$ gene by cAMP during preadipocyte differentiation. Proc. Natl. Acad. Sci. 86: 3629-3633.

Yokoyama, K. and F. Imamoto. 1987. Transcriptional control of the endogenous MYC protooncogene by antisense RNA. Proc. Natl. Acad. Sci. 84: 7363-7367. 


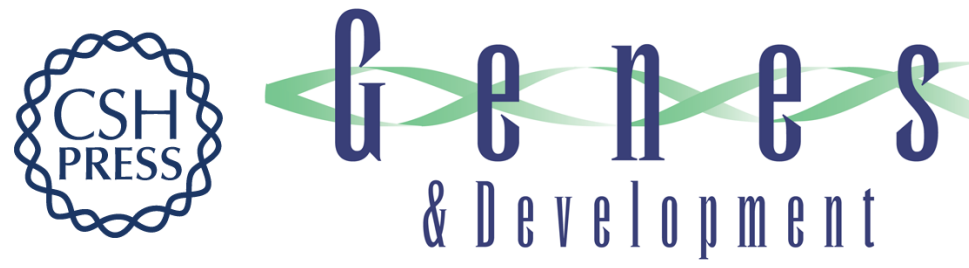

\section{Antisense CCAAT/enhancer-binding protein RNA suppresses coordinate gene expression and triglyceride accumulation during differentiation of 3T3-L1 preadipocytes.}

F T Lin and M D Lane

Genes Dev. 1992, 6:

Access the most recent version at doi:10.1101/gad.6.4.533

References This article cites 59 articles, 37 of which can be accessed free at: http://genesdev.cshlp.org/content/6/4/533.full.html\#ref-list-1

License

Email Alerting Service

Receive free email alerts when new articles cite this article - sign up in the box at the top right corner of the article or click here.

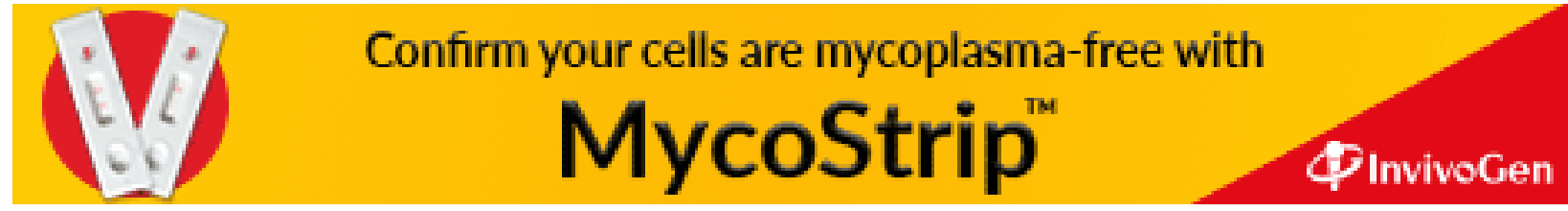

